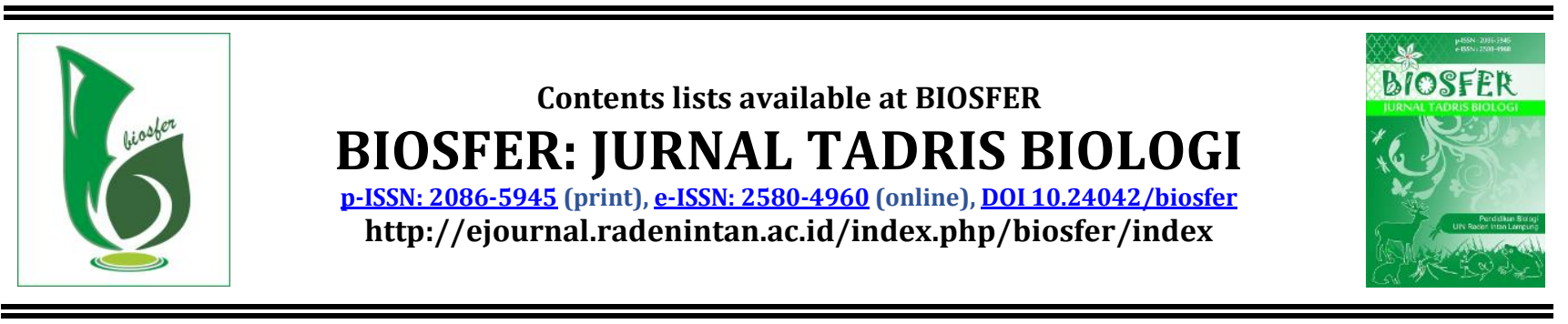

\title{
The Digestibility of Banana Peel and Testa coconut and Its Effects on the Growth and Mortality of Black Soldier Fly Larvae (Hermetia illucens) at Constant Feeding Rates
}

\author{
Ramadhani Eka Putra ${ }^{*}$, Alfariana Margareta² ${ }^{2}$ Ida Kinasih ${ }^{3}$ \\ 1, 2, Sekolah Ilmu dan Teknologi Hayati - Institut Teknologi Bandung, Indonesia \\ 3 Universitas Islam Negeri Sunan Gunung Djati Bandung, Indonesia
}

\section{ARTICLE INFO}

\section{Article History}

Received: April 14th 2020

Accepted: May $18^{\text {th }}, 2020$

Published: June 29th 2020

\section{Keywords:}

Decomposition

Hermetia illucens;

Banana peel;

Testa coconut;

WRI (Waste Reduction

Index);

ECD (Efficiency of Conversion of Digested Feed).

*Correspondence Address: ramadhani@sith.itb.ac.id

\begin{abstract}
Organic waste produced by economic activities may create health, aesthetic, and economic problems. One of the approaches applied to solve this problem is the utilization of decomposer macrofauna to decompose the waste. One of the decomposers with great potential is Black Soldier Fly larvae (Hermetia illucens) that can consume various types of organic wastes and converts it into biomass with high protein and lipid content. In this study, banana peels and coconut testa had been fed to the larvae at $200 \mathrm{mg} /$ larvae/day as the objects that represented organic wastes with low fiber content and high fiber content respectively. The purpose of this study was to observe the growth and efficiency of BSF larvae in decomposing those wastes. The analysis was conducted on some parameters such as the growth and consumption rate, the efficiency of conversion of digested (ECD), waste reduction index, and mortality rate. The results showed that BSF larvae THAT consumed banana peel had a higher final weight $(58.24 \mathrm{mg})$, growth rate, and consumption rate while the mortality rate was lower than BSF larvae that consumed coconut testa. The ECD of the larvae group that consumed banana peel was higher than the larvae group that consumed coconut testa. The waste reduction index of banana peel was higher than coconut testa (1.5 and 1.4, respectively). The larvae that consumed coconut testa had a longer pupation period $(9 \pm 1,75$ days) compared to the larvae that consumed banana peel. Based on this result, it can be concluded that the fiber content of organic waste affected the decomposition rate and growth of BSF larvae.
\end{abstract}

Kemampuan cerna kulit pisang dan testa kelapa dan efeknya pada pertumbuhan dan mortalitas larva Black Soldier Fly (Hermetiaillucens) pada tingkat pemberian pakan konstan

Abstrak: Sampahorganik yang dihasilkan dari aktivitas ekonomi manusia dapat menimbulkan masalah kesehatan, estetika, dan ekonomi, Salah satupendekatan yang mulai banyak diaplikasikan adalah pemanfaatan macrofauna decomposer untuk mendekom posisi sampah tersebut. Salah 
Biosfer: Jurnal Tadris Biologi, 11 (1) (2020) 66 - 77

Ramadhani Eka Putra, Alfariana Margareta, Ida Kinasih

\begin{abstract}
satu agenda komposisi yang potensial adalah larva Black Soldier Fly (BSF)(Hermetiaillucens) yang memiliki kemampuan mengkonsumsi limbah organik dan merubahnya menjadi biomasa tubuh dengan kandungan protein dan lipid tinggi. Pada penelitian ini dipilih sampah kulit pisang dan testakelapa (diberikan dalam jumlah200 mg/larva/hari) sebagai objek penelitian untuk mewakili sampah organic dengan kandungan serat rendah dan tinggi. Tujuan penelitian ini adalah untuk mengetahui pertumbuhan dan efisiensi larva BSF dalam mendegradasi produk buangan buah pisang dan kelapa. Analisa dilakukan terhadap beberapa parameter seperti laju pertumbuhan, laju konsumsi, Efficiency of Conversion of Digested (ECD), Waste Reduction Index (WRI) dan mortalitas dari larva BSF. Hasil penelitian menunjukkan bahwa kelompok larva BSF yang mengkonsumsi kulit pisang memiliki beratakhir (58,24 mg) dengan laju pertumbuhan dan tingkat konsumsi lebih tinggi serta tingkat mortalitas lebih rendah dibandingkan kelompok yang mengkonsumsi testa kelapa (48,72 mg). Nilai ECD pada kelompok larva yang mengkonsumsi kulit pisang (13,02\%) lebih tinggi dibandingkan pada kelompok yang mengkonsumsi testa kelapa adalah (12,45\%). Nilai efisiensi reduksi (WRI) kulit pisang lebih tinggi dibandingkan testa kelapa (1,5 dan 1,4 secara berurutan). Konsumsi testa kelapa menghasilkan pupa yang membutuhkan masa pupasi lebih lama (9 $\pm 1,75$ hari) dibandingkan

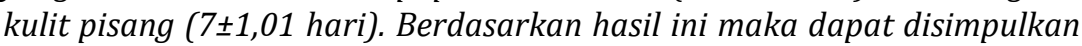
bahwa kandungan serat pada limbah organic sangat mempengaruhi kemampuan dekomposisi dan pertumbuhan dari larva BSF.
\end{abstract}

\section{INTRODUCTION}

One of the common types of waste produced by human economic activities is organic waste. Organic waste is generally processed using the sanitary landfill method or through a composting process to reduce its volume. However, the final product of the two processes is an only organic fertilizer which has relatively limited added value. This has caused the processing of organic waste to get relatively less attention, although the pile of organic waste affects the health, aesthetics, and the possibility of increasing the production of greenhouse gases that have the potential to change the climate (Bogner et al., 2011). Recently, an effort has been developed by upcycling organic waste through a bioconversion process using a decomposer, known as CORS (Conversion of Organic Refuse by Saprophages).

At CORS, the process of overhauling organic waste is performed by the saprophage biomass through the metabolic process (Diener et al., 2009). One of the biological agents that can be used in the CORS process is the black soldier fly larvae (Hermetia illucens). Larvae of this species have been known to have the ability to consume various types of organic waste such as livestock manure (Q. Li et al., 2011; Rehman et al., 2017; Zhou et al., 2013), food waste (Kinasih et al., 2018; Parra Paz et al., 2015; Salomone et al., 2017), and organic waste of economic-based activity (Diener et al., 2011; W. Li et al., 2015; Manurung, Supriatna, \& Esyanthi, 2016). This consumption process produces a body biome which is rich in protein and lipids as potential raw materials for protein and lipid-based bio-industries such as animal feed (Khan, 2018), biofuels (Zheng, Hou, et al., 2012; Zheng, Li, et al., 2012), nutrients (Wang \& Shelomi, 2017), and metabolic residues that have the potential as organic fertilizer (Setti et al., 2019). This process can also provide more initiative to waste management because of the additional values contained in the end products (upcycling) (Čičková et al., 2015; Lohri et al., 2017). 
One of the main bio-based economic activities in Indonesia is the processed fruit products which produce a large amount of organic waste. Broadly speaking, there are two types of fruit that are used as raw material for processed products, namely fruit with low cellulose fiber content and high cellulose fiber content. This phenomenon served as the foundation of this research which utilized the wastes of processed banana and coconut fruit industry as the model.

Banana is one of the leading fruit commodities in Indonesia which keeps increasing every year. This is indicated by the average production data of banana which increased by $9.29 \%$ in 2010-2014 (Dirjen Hortikultura Kementerian Pertanian, 2015). On the other hand, the average coconut production in Indonesia reaches 15.5 billion pieces/year (Mahmud \& Yulius, 2004). This condition has led to the growth of banana and coconut processing industries which produce 2 main wastes, namely banana peels and coconut testa.

Both types of wastes contain nutrients that can be used as raw material for metabolic processes by BSF larvae, especially the protein and crude fiber. Banana peel contains 1\% protein and $30 \%$ crude fiber (Anhwange et al., 2009) while coconut testa contains $7 \%$ protein and $17 \%$ crude fiber (Appaiah et al., 2014). This condition causes these two materials to have potential as raw materials for the bioconversion process by BSF larvae. Based on the description, this research was aimed to obtain information related to the efficiency of the bioconversion process of banana peels and coconut testa by BSF larvae.

\section{METHOD}

\section{Research Preparation}

BSF larvae used in this study came from eggs produced by the Balai Riset Budidaya Ikan Hias (BRBIH), Depok. The eggs were hatched on a medium of commercial chicken feed mixed with water to reach a water content of $60 \%(\mathrm{w} / \mathrm{w})$. The larvae used in the study were larvae aged 7 days after hatching.

\section{Treatment}

Two BSF queens and larvae were placed in two plastic cups (16 oz volume) covered with holed plastic caps ( 9 total holes with a diameter of $5 \mathrm{~mm}$ each). Each cup and the cap were held together by rubber bands and coated with black plastics on the sides of the cups. The first cup was given banana peels and the second cup was given coconut testa with an amount of $200 \mathrm{mg} / \mathrm{larva} /$ day. The treatment was repeated 5 times. The larvae were placed in the room temperature (23$28^{\circ} \mathrm{C}$ ) with a relative humidity of $70-80 \%$.

Every 3 days, $5 \%$ of the total larvae contained in the plastic cups were randomly sampled to obtain the larvae dry weight. The larvae were put in an oven at $60^{\circ} \mathrm{C}$ for 24 hours and the dry weight was determined by the gravimetric method. The observation and feeding were carried out until $50 \%$ of the larvae entered the prepupa period which was characterized by a dark change in color and inactive movement.

\section{The Determination of the Growth Rate and the Consumption Rate}

The dry weight of the larvae was used as the basis to determine the growth rate and consumption rate using the formula(Fogg, 1975):

Growth Rate $=\frac{\ln B t-\ln B o}{t}$
Consumption Rate $=\frac{\ln K t-\ln K o}{t}$

$B_{t}$ is the weight of larvae after t-day, $B_{0}$ is the initial weight of larvae, and $t$ is the time of observation (days). $\mathrm{K}_{\mathrm{t}}$ is the total consumption 
of larvae after t-day, $\mathrm{K}_{0}$ is the amount of initial consumption of larvae, and $t$ is the time of observation (days).

In this research, the duration of the pupation period was the time spent by the pupa before becoming an adult insect.

\section{The Determination the Consumption Process Efficiency}

The growth of living things is determined by their ability to digest the food they have consumed. In this research, the level of food conversion efficiency was measured through the Efficiency of Conversion of Digested Food (ECD) using the following equation (Scriber \& Slansky, 1981):

$$
\begin{array}{ll}
\mathrm{B} & =(\mathrm{I}-\mathrm{F})-\mathrm{M} \\
\mathrm{ECD} & =\mathrm{B} / \mathrm{I}-\mathrm{F}
\end{array}
$$

$B$ is the assimilation of food used for growth (calculated as pre-pupa biomass), I is the total food given during the research, $\mathrm{F}$ is the residue in the plastic container (leftover feed + excretion product), and $\mathrm{M}$ is the food that has been assimilated for metabolism.

\section{The Determination of WRI}

One of the objectives of this study was to obtain information regarding the ability of larvae to reduce the amount of organic waste. This ability is expressed in the Reduction Index (WRI) based on the following equation:

$$
\begin{array}{ll}
\mathrm{WRI} & =\mathrm{D} / \mathrm{t} \times 100 \\
\mathrm{D} & =(\mathrm{WR}) / \mathrm{W}
\end{array}
$$

$\mathrm{W}$ is the total feed given during the treatment, $\mathrm{t}$ is the time of observation, and $\mathrm{R}$ is the metabolic residue and unconsumed food (Diener et al., 2009).

\section{RESULTS AND DISCUSSION}

\section{The Growth of Larvae}

The growth pattern between the two groups of larvae (banana peel group and coconut testa) followed the same growth pattern where there was a continuous increase until the end of the observation (Figure 1). During the growth period, the biomass value of the banana peels group larvae was higher than the coconut testa group larvae (Figure 1)

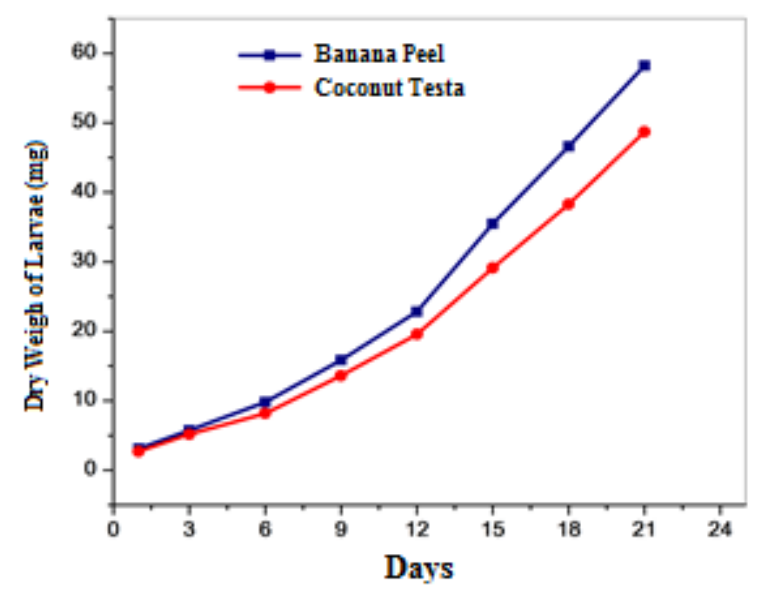

Figure 1. The Biomass Changes of BSF Larvae

The difference in body weight may be related to the nutrient content of the feed. The final weight of larvae that consumed banana peels was different with the results of the research conducted by (Isibika et al., 2019) who had reported that the final weight of the BSF larvae that consumed Awak banana peels was $33 \pm 2 \mathrm{mg}$ and $134 \pm 3 \mathrm{mg}$ for the larvae that consumed Cavendish banana peels. The value difference was caused by different types of bananas peels with different nutrient contents, the quality of feed (Cammack \& Tomberlin, 2017; Chia et al., 2018; Gobbi, Martínez-Sánchez, et al., 2013) especially the ratio of protein and digestible fiber, and the total fiber content (Lalander et al., 2019; Tschirner \& Simon, 2015). This could also explain why the larvae that consumed coconut testa had relatively lower growth rates.

On the other hand, the growth pattern of larvae did not show any horizontal curve that indicates the halt of the growth 
process and metamorphosis from larvae to pre-pupa (Sripontan et al., 2020). Similar growth patterns were found by (Manurung, Supriatna, \& Esyanthi, 2016) who used basic ingredients rich in Hemi- and lingo cellulose. Based on this, it can be assumed that the feed contained a relatively high indigestible carbohydrate.

The results of the larval growth rate analysis showed that the larvae fed with banana peels had a slightly higher growth rate than the one fed with coconut testa $(0.08$ and $0.07 \mathrm{mg} /$ day $)$ although they were not significantly different. The growth rate decreases over time (Figure 2).

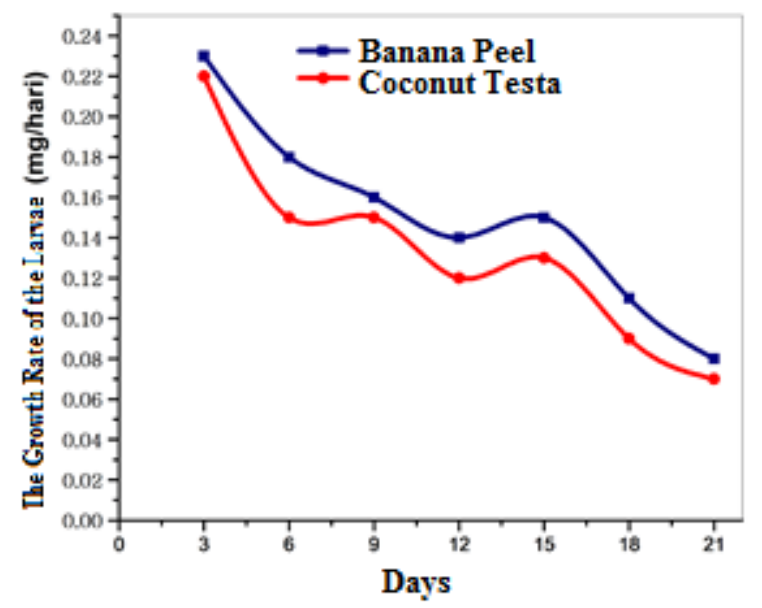

Figure 2. The Growth Rate of the Larvae

There was a decreased weight gain because the BSF larvae were unable to digest their food properly due to the high indigestible carbohydrate content (Liu et al., 2018). The lignin content of the coconut testa made the BSF larvae can only absorb low nutrient level because the BSF larvae have difficulty in digesting lignin (Zheng, Li, et al., 2012) which is usually assisted by certain symbiotic activity in the insect digestive system (Ohkuma, 2003). On the other hand, the banana peels used in this study may contain a large amount of slowly digestible starch (Z. Li et al., 2018).

\section{The Mortality Rate of the Larvae}

The mortality rate of the BSF larvae decreased as they aged. The larvae fed with banana peel had a better rate (Figure 3 ). In total, the mortality rate of the larvae fed with banana was $78.6 \%$ (393 larvae out of 500 ) while the mortality rate of the larvae fed with coconut testa was $68.2 \%$ (341 larvae out of 500).

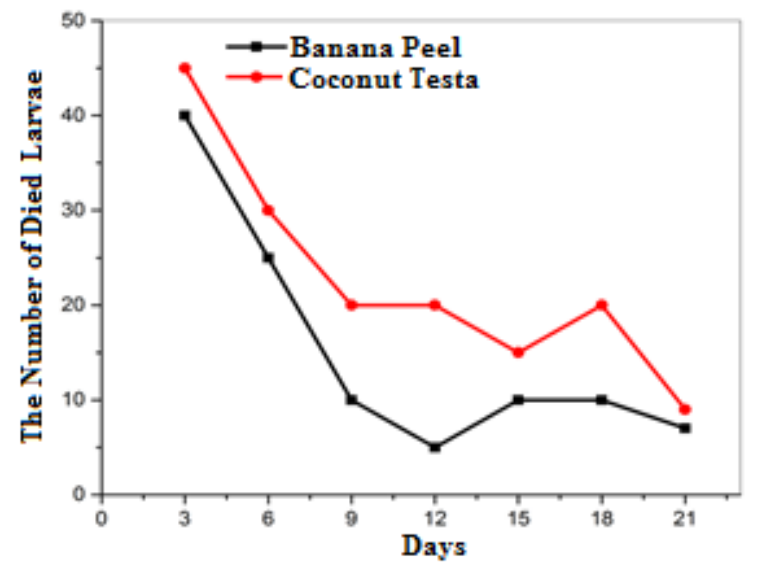

Figure 3. The Mortality Rate of the BSF Larvae

A similar decreased mortality rate was also reported by (Gao et al., 2019). This could be related to increased biomass and the protection from environmental influences along with the increased protection of the cuticles.

Compared to other studies, the survival rates of BSF larvae in this research were equivalent to the results of studies using a single type of feed with high carbohydrate content (Table 1). This indicated that the larvae can only take carbohydrates from the feed given in this research. This condition had caused an imbalance in nutrition which resulted in a low survival rate.

Table 1. The Mortality Rate Comparison of BSF Larvae with Other Studies

\begin{tabular}{llc}
\hline Reference & Feeds & $\begin{array}{c}\text { Mortality Rates } \\
\text { (\%) }\end{array}$ \\
\hline This Research & Banana Peel & 78,6 \\
& Coconut & 68,2 \\
(Ewald et al., & Bread & 69.8 \\
2020) & Meat & 18,4 \\
& Leftovers & 89,1 \\
& Fresh & 89,3 \\
& Crunches & \\
& Rotten Shells & 55,1 \\
& Bread and & $54,3-86,2$ \\
& Shellfish & \\
\hline
\end{tabular}




\begin{tabular}{|c|c|c|}
\hline (Danieli et al., & Non-fiber & 66 \\
\hline 2019) & High & \\
\hline & Carbohydrate & \\
\hline & Content & \\
\hline & High Fiber & 81 \\
\hline & Content & \\
\hline & High Protein & 67 \\
\hline & Content & \\
\hline (ur Rehman et & Cows and & $89,5-98,4$ \\
\hline al., 2017) & Chickens' & \\
\hline & Manure & \\
\hline (Manurung, & Hay & $51,2-98,3$ \\
\hline Supriatna, & & \\
\hline $\begin{array}{l}\text { Esyanthi, et } \\
\text { al., 2016) }\end{array}$ & & \\
\hline $\begin{array}{l}\text { (D. Oonincx et } \\
\text { al., 2015) }\end{array}$ & Artificial Feed & $75-85$ \\
\hline (D. G. Oonincx & Cow Manure & 87,8 \\
\hline et al., 2015) & Chicken & 82,2 \\
\hline & Manure & \\
\hline & Pig Manure & 97 \\
\hline (Gobbi, & Chicken Feed & 93 \\
\hline Martinez- & Meat & 40 \\
\hline $\begin{array}{l}\text { Sanchez, et al., } \\
\text { 2013) }\end{array}$ & & \\
\hline $\begin{array}{l}\text { (Myers et al., } \\
2014 \text { ) }\end{array}$ & Cow Manure & $71-85$ \\
\hline
\end{tabular}

\section{The Pupation Period Development}

Larvae fed with banana peel had a shorter pupation period compared to the larvae fed with coconut testa (7 days versus 9 days) (Table 1).

Table 2. Comparison with other Studies

\begin{tabular}{|c|c|c|}
\hline Reference & Feeds & $\begin{array}{l}\text { Pupation } \\
\text { Period }\end{array}$ \\
\hline This Research & Banana Peel & $7 \pm 1,01$ \\
\hline & Coconut Testa & $9 \pm 1,75$ \\
\hline $\begin{array}{l}\text { (Gao et al., } \\
2019)\end{array}$ & $\begin{array}{l}\text { Wheat Straw } \\
\text { Fermented } \\
\text { Wheat Straw }\end{array}$ & $\begin{array}{l}9,25 \pm 0,16 \\
9,22 \pm 0,12\end{array}$ \\
\hline
\end{tabular}

The pupation period of the larvae fed with coconut testa was relatively similar to the research results of (Gao et al., 2019) (Tabel 2). This indicates that the nutritional content in coconut testa is equivalent to that of wheat straw. The duration of the pupa development process is determined by the hormonal processes of the residual nutrient during the larvae stage (Nijhout, 2003; Telang et al., 2007), especially sugar and protein (MacWhinnie et al., 2005). This could explain why the pupation period of the larvae group fed with banana peels was shorter than the group fed with coconut testa based on the likelihood of getting sugar and protein. On the other hand, the water content of the banana peels had a higher positive effect on the process of the accumulation of nutrients during the larval stage to be used in the pupation period (Cheng et al., 2017; Dzepe et al., 2019).

\section{The Consumption Process Efficiency}

The consumption rate of the BSF larvae fed with banana peels was higher (0.2 $\mathrm{mg} /$ day) than the larvae fed with coconut testa $(0.18 \mathrm{mg} /$ day) (Figure 4$)$. This data indicated that banana peel was to consume.

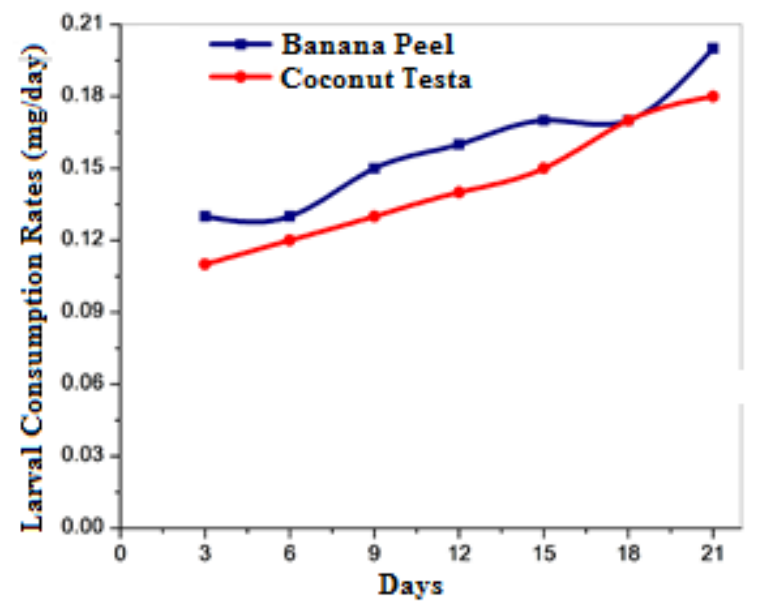

Figure 4. The Consumption Rate of the BSF larvae

The low consumption level of BSF larvae fed with coconut testa was associated with lower consumption process efficiency (Figure 5). 


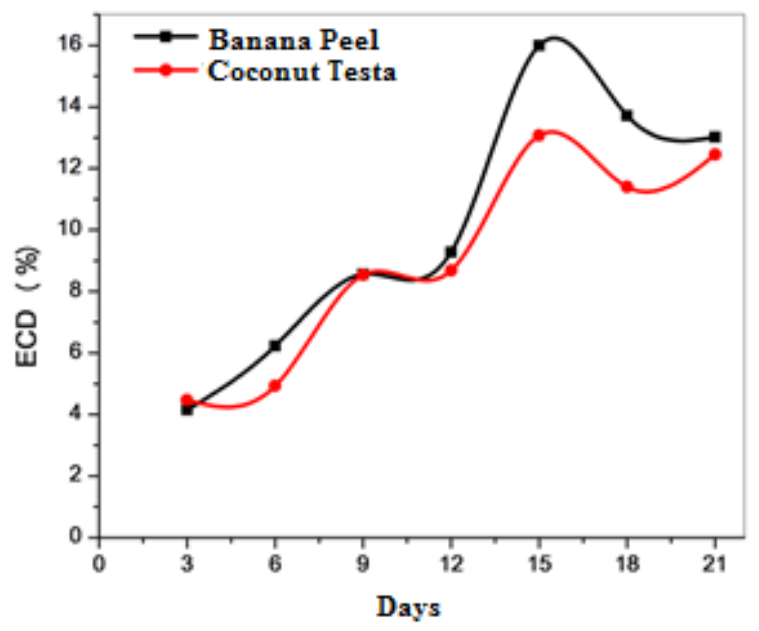

Figure 5. The Consumption Process Efficiency of the BSF Larvae

Both consumption patterns showed an increasing consumption rate and efficiency as the larva aged. This was related to the nutrients accumulation process for hormone formation in further metamorphosis stage. On the other hand, a more balanced nutritional content in banana peels led to a more efficient consumption process (Cammack \& Tomberlin, 2017).

This might be caused by the lower water content of coconut testa compared to banana peels. Water content plays an important role in the absorption of food and the reduction of energy needed to carry out the metabolic process. Another factor that can also cause coconut testa's ECD to be lower is the lingo cellulose component. This compound requires cellulose enzymes in the digestion process which can be produced by the larvae themselves (Taggar, 2015). Several studies have shown that BSF larvae can produce this enzyme themselves (Lee et al., 2014) or by using symbiotes in the form of microorganisms present in the digestive tract (De Smet et al., 2018; Supriyatna \& Ukit, 2016).

The low consumption efficiency caused a change in the feed allocation strategy. The number of banana peels used to produce biomass was $29.12 \%$ and the metabolism was $11.01 \%$ with a residue of $59.87 \%$. On the other hand, the proportion of coconut testa used as biomass was $25.46 \%$ and the metabolism was $19.62 \%$ with a residue of $54.92 \%$ (Figure 4 ).

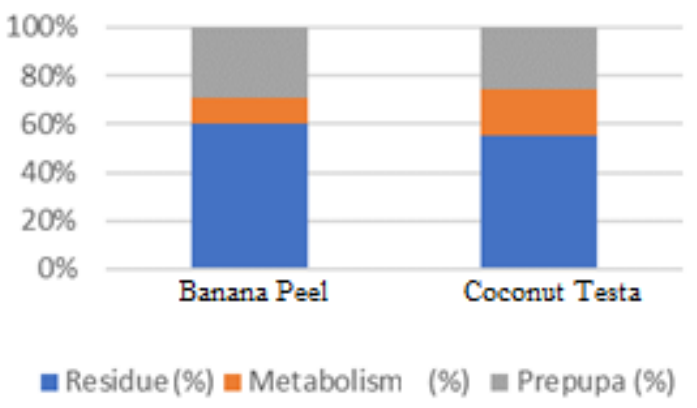

Figure 6. Feed Allocation for Biomass, Metabolism, and Residue

More coconut testa was allocated due to its poor quality to support the metabolism to sustain the life of the larvae. This strategy is commonly used for insects when they can not obtain optimal amounts of nutrition until they can obtain a better feed so that they can allocate it for the growth process (known as compensatory growth) (Dmitriew, 2011; Mangel \& Munch, 2005).

\section{The Efficiency of the Waste Reduction Process}

The BSF larvae were more efficient to reduce banana peel waste compared to the coconut testa waste. The WRI values of banana peels are 1.5 and coconut testa is 1.4 (Figure 7). The values increased along with time. The higher the WRI value, the better the waste reduction efficiency which might relate to the increased rate and efficiency of the consumption process. 


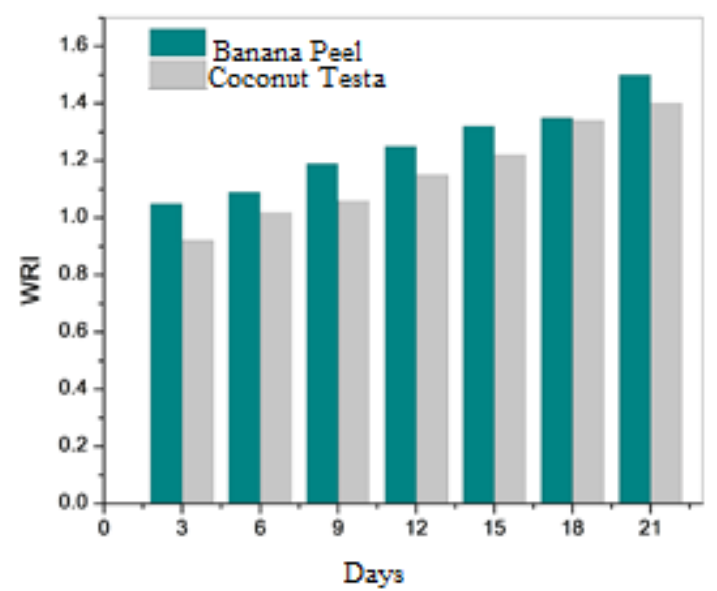

Figure 7. Waste Reduction Index of the BSF Larvae

When compared to other studies, the banana peel and coconut testa waste reduction rates by the $\mathrm{BSF}$ larvae were relatively low (Table 3 ). This can be corrected by using a co-conversion process using microorganisms (Appaiah et al. 2014) or controlling the ratio of carbon and nitrogen of the wastes (Palma et al., 2019).

Table 3. The Comparison of the BSF Larvae Mortality Rate with Other Studies

\begin{tabular}{|c|c|c|}
\hline References & Feeds & $\begin{array}{l}\text { Waste } \\
\text { Reduction } \\
\text { Rates (\%) }\end{array}$ \\
\hline This & Banana peels & 1,50 \\
\hline Research & Coconut testa & 1,40 \\
\hline (Jucker et & Crickets' waste & $3,12-4,5$ \\
\hline \multirow{5}{*}{$\begin{array}{l}\text { (Meneguz } \\
\text { et al., 2018) }\end{array}$} & Grasshoppers' waste & $1,32-1,79$ \\
\hline & $\begin{array}{l}\text { Fruit and vegetable } \\
\text { mixture }\end{array}$ & 3,2 \\
\hline & Fruit & 3,2 \\
\hline & Grape Industrial waste & 2,4 \\
\hline & Beer industrial waste & 5,3 \\
\hline $\begin{array}{l}\text { (Hakim et } \\
\text { al., 2017) }\end{array}$ & Fish industrial waste & $3,37-4,06$ \\
\hline
\end{tabular}

\section{CONCLUSIONS AND SUGGESTIONS}

BSF larvae (H. illucens) were able to consume and convert banana peels and coconut testa into biomass. Banana peel is a better feed for larvae as indicated by the development of better pupation period and ECD. There was no difference in the BSF larvae's ability to reduce the two types of organic wastes which indicated that the nutritional qualities of the two types of wastes were relatively the same.

\section{REFERENCES}

Anhwange, B. A., Ugye, T. J., \& Nyiaatagher, T. D. (2009). Chemical composition of Musa sapientum (Banana) peels. Electronic Journal of Environmental, Agricultural and Food Chemistry, 8(6), 437-442.

Appaiah, P., Sunil, L., Prasanth Kumar, P. K., \& Gopala Krishna, A. G. (2014). Composition of coconut testa, coconut kernel and its oil. JAOCS, Journal of the American Oil Chemists' Society, 91(6), 917-924. https://doi.org/10.1007/s11746-0142447-9

Bogner, J. E., Spokas, K. A., \& Chanton, J. P. (2011). Seasonal greenhouse gas emissions (methane, carbon dioxide, nitrous oxide) from engineered landfills: Daily, intermediate, and final California cover soils. Journal of Environmental Quality, 40(3), 10101020.

https://doi.org/10.2134/jeq2010.0407

Cammack, J. A., \& Tomberlin, J. K. (2017). The impact of diet protein and carbohydrate on select life-history traits of the black soldier fly Hermetia illucens (L.) (Diptera: Stratiomyidae). Insects, $8(2)$. https://doi.org/10.3390/insects802005 6

Cheng, J. Y. K., Chiu, S. L. H., \& Lo, I. M. C. (2017). Effects of moisture content of food waste on residue separation, larval growth and larval survival in black soldier fly bioconversion. Waste Management, 67(June 2017), 315323. 
https://doi.org/10.1016/j.wasman.2017 .05 .046

Chia, S. Y., Tanga, C. M., Osuga, I. M., Mohamed, S. A., Khamis, F. M., Salifu, D., Sevgan, S., Fiaboe, K. K. M., Niassy, S., van Loon, J. J. A., Dicke, M., \& Ekesi, S. (2018). Effects of waste stream combinations from brewing industry on performance of black soldier fly, Hermetia illucens (Diptera: Stratiomyidae). PeerJ, 2018(11), 1-26. https://doi.org/10.7717/peerj.5885

Čičková, H., Newton, G. L., Lacy, R. C., \& Kozánek, M. (2015). The use of fly larvae for organic waste treatment. Waste Management (New York, N.Y.), 35 , 68-80. https://doi.org/10.1016/j.wasman.2014 .09 .026

Danieli, P. P., Lussiana, C., Gasco, L., Amici, A., \& Ronchi, B. (2019). The effects of diet formulation on the yield, proximate composition, and fatty acid profile of the black soldier fly (Hermetia illucens L.) prepupae intended for animal feed. Animals, 9(4), 178.

De Smet, J., Wynants, E., Cos, P., \& Van Campenhout, L. (2018). Microbial Community Dynamics during Rearing of Black. Applied and Environmental Microbiology, 84(9), 1-17. https://doi.org/10.1128/AEM .0272217

Diener, S., Studt Solano, N. M., Roa Gutiérrez, F., Zurbrügg, C., \& Tockner, K. (2011). Biological Treatment of Municipal Organic Waste using Black Soldier Fly Larvae. Waste and Biomass Valorization, 2(4), 357-363. https://doi.org/10.1007/s12649-0119079-1
Diener, S., Zurbrügg, C., \& Tockner, K. (2009). Conversion of organic material by black soldier fly larvae: Establishing optimal feeding rates. Waste Management and Research, 27(6), 603-610. https://doi.org/10.1177/0734242X091 03838

Dirjen Hortikultura Kementerian Pertanian. (2015). Statistik Produksi Hortikultura Tahun 2014.

Dmitriew, C. (2011). The evolution of growth trajectories: What limits growth rate? Biological Reviews of the Cambridge Philosophical Society, 86, 97-116. https://doi.org/10.1111/j.1469185X.2010.00136.X

Dzepe, D., Nana, P., \& Tchuinkam, T. (2019). Influence of larval density, substrate moisture content and feedstock ratio on life history traits of black soldier fly larvae.

Ewald, N., Vidakovic, A., Langeland, M., Kiessling, A., Sampels, S., \& Lalander, C. (2020). Fatty acid composition of black soldier fly larvae (Hermetia illucens)-Possibilities and limitations for modification through diet. Waste Management, 102, 40-47.

Fogg, G. E. (1975). Algae Culture and Phytoplankton Ecology (Second Edi). Maddison: University of Winconsin Press.

Gao, Z., Wang, W., Lu, X., Zhu, F., Liu, W., Wang, X., \& Lei, C. (2019). Bioconversion performance and life table of black soldier fly (Hermetia illucens) on fermented maize straw. Journal of Cleaner Production, 230(May), 974-980. https://doi.org/10.1016/j.jclepro.2019. 05.074 
Gobbi, P., Martínez-Sánchez, A., \& Rojo, S. (2013). The effects of larval diet on adult life-history traits of the black soldier fly, Hermetia illucens (Diptera: Stratiomyidae). European Journal of Entomology, 110(3), 461-468. https://doi.org/10.14411/eje.2013.061

Gobbi, P., Martinez-Sanchez, A., \& Rojo, S. (2013). The effects of larval diet on adult life-history traits of the black soldier fly, Hermetia illucens (Diptera: Stratiomyidae). European Journal of Entomology, 110(3), 461.

Hakim, A. R., Presetyo, A., \& Petrus, H. B. M. (2017). Potensi Larva Hermetian illucens Sebagai Pereduksi Limbah Industry Pengolahan Hasil Perikanan. Jurnal Perikanan, 39-44.

Isibika, A., Vinnerås, B., Kibazohi, O., Zurbrügg, C., \& Lalander, C. (2019). Pre-treatment of banana peel to improve composting by black soldier fly (Hermetia illucens (L.), Diptera: Stratiomyidae) larvae. Waste Management, 100, 151-160. https://doi.org/10.1016/j.wasman.2019 .09 .017

Jucker, C., Lupi, D., Moore, C. D., Leonardi, M. G., \& Savoldelli, S. (2020). Nutrient recapture from insect farm waste: Bioconversion with hermetia illucens (L.)(Diptera: Stratiomyidae). Sustainability, 12(1), 362.

Khan, S. H. (2018). Recent advances in role of insects as alternative protein source in poultry nutrition. Journal of Applied Animal Research, 46(1), 1144-1157. https://doi.org/10.1080/09712119.201 8.1474743

Kinasih, I., Putra, R. E., Permana, A. D., Gusmara, F. F., Nurhadi, M. Y., \& Anitasari, R. A. (2018). Growth performance of black soldier fly larvae (Hermetia illucens) fed on some plant based organic wastes. HAYATI Journal of Biosciences, 25(2), 79-84. https://doi.org/10.4308/hjb.25.2.79

Lalander, C., Diener, S., Zurbrügg, C., \& Vinnerås, B. (2019). Effects of feedstock on larval development and process efficiency in waste treatment with black soldier fly (Hermetia illucens). Journal of Cleaner Production, 208(October), 211-219. https://doi.org/10.1016/j.jclepro.2018. 10.017

Lee, C. M., Lee, Y. S., Seo, S. H., Yoon, S. H., Kim, S. J., Hahn, B. S., Sim, J. S., \& Koo, B. S. (2014). Screening and characterization of a novel cellulase gene from the gut microflora of Hermetia Illucens using metagenomic library. Journal of Microbiology and Biotechnology, 24(9), 1196-1206. https://doi.org/10.4014/jmb.1405.0500 1

Li, Q., Zheng, L., Qiu, N., Cai, H., Tomberlin, J. K., \& Yu, Z. (2011). Bioconversion of dairy manure by black soldier fly (Diptera: Stratiomyidae) for biodiesel and sugar production. Waste Management, 31(6), 1316-1320. https://doi.org/10.1016/j.wasman.2011 .01 .005

Li, W., Li, Q., Zheng, L., Wang, Y., Zhang, J., Ziniu, yu, \& Zhang, Y. (2015). Potential biodiesel and biogas production from corncob by anaerobic fermentation and black soldier fly. Bioresource Technology, 194, 276282.

https://doi.org/10.1016/j.biortech.2015 .06 .112

Li, Z., Guo, K., Lin, L., He, W., Zhang, L., \& Wei, C. (2018). Comparison of physicochemical properties of starches from flesh and Peel of Green Banana Fruit. Molecules, 23(9), 1-15. 
https://doi.org/10.3390/molecules2309 2312

Liu, Z., Minor, M., Morel, P. C. H., \& NajarRodriguez, A. J. (2018). Bioconversion of Three Organic Wastes by Black Soldier Fly (Diptera: Stratiomyidae) Larvae. Environmental Entomology, 47(6), 1609-1617. https://doi.org/10.1093/ee/nvy141

Lohri, C. R., Diener, S., Zabaleta, I., Mertenat, A., \& Zurbrügg, C. (2017). Treatment technologies for urban solid biowaste to create value products: A review with focus on low- and middleincome settings. Reviews in Environmental Science and Biotechnology, 16(1), 81-130. https://doi.org/10.1007/s11157-0179422-5

MacWhinnie, S. G. B., Allee, J. P., Nelson, C. A., Riddiford, L. M., Truman, J. W., \& Champlin, D. T. (2005). The role of nutrition in creation of the eye imaginal disc and initiation of metamorphosis in Manduca sexta. Developmental Biology, 285(2), 285297.

https://doi.org/10.1016/j.ydbio.2005.0 6.021

Mahmud, Z., \& Yulius, D. A. N. (2004). Prospek Pengolahan Hasil Samping Buah Kelapa. 1.

Mangel, M., \& Munch, S. B. (2005). A lifehistory perspective on short- and longterm consequences of compensatory growth. The American Naturalist, 166(6). https://doi.org/10.1086/444439

Manurung, R., Supriatna, A., \& Esyanthi, R. R. (2016). Bioconversion of Rice straw waste by black soldier fly larvae ( Hermetia illucens L .): Optimal feed rate for biomass production. Journal of Entomology and Zoology Studies, 4(4), 1036-1041.
Manurung, R., Supriatna, A., Esyanthi, R. R., \& Putra, R. E. (2016). Bioconversion of rice straw waste by black soldier fly larvae (Hermetia illucens L.): Optimal feed rate for biomass production. $J$. Entomol. Zool. Stud, 4(4), 1036-1041.

Meneguz, M., Schiavone, A., Gai, F., Dama, A., Lussiana, C., Renna, M., \& Gasco, L. (2018). Effect of rearing substrate on growth performance, waste reduction efficiency and chemical composition of black soldier fly (Hermetia illucens) larvae. Journal of the Science of Food and Agriculture, 98(15), 5776-5784.

Myers, H. M., Tomberlin, J. K., Lambert, B. D., \& Kattes, D. (2014). Development of black soldier fly (Diptera: Stratiomyidae) larvae fed dairy manure. Environmental Entomology, 37(1), 11-15.

Nijhout, H. F. (2003). The control of body size in insects. Developmental Biology, 261(1), 1-9. https://doi.org/10.1016/S00121606(03)00276-8

Ohkuma, M. (2003). Ohkuma M.. Termite symbiotic systems: Efficient biorecycling of lignocellulose. Appl Microbiol Biotechnol 61: 1-9. Applied Microbiology and Biotechnology, 61, 1-9. https://doi.org/10.1007/s00253002-1189-z

Oonincx, D. G., Van Broekhoven, S., Van Huis, A., \& van Loon, J. J. (2015). Feed conversion, survival and development, and composition of four insect species on diets composed of food by-products. PloS One, 10(12), e0144601.

Oonincx, D., Van Huis, A., \& Van Loon, J. J. A. (2015). Nutrient utilisation by black soldier flies fed with chicken, 
pig, or cow manure. Journal of Insects as Food and Feed, 1(2), 131-139.

Palma, L., Fernandez-Bayo, J., Niemeier, D., Pitesky, M., \& VanderGheynst, J. S. (2019). Managing high fiber food waste for the cultivation of black soldier fly larvae. Npj Science of Food, $3(1)$. https://doi.org/10.1038/s41538-0190047-7

Parra Paz, A. S., Carrejo, N. S., \& Gómez Rodríguez, C. H. (2015). Effects of Larval Density and Feeding Rates on the Bioconversion of Vegetable Waste Using Black Soldier Fly Larvae Hermetia illucens (L.), (Diptera: Stratiomyidae). Waste and Biomass Valorization, 6(6), 1059-1065. https://doi.org/10.1007/s12649-0159418-8

Rehman, K., Cai, M., Xiao, X., Zheng, L., Wang, H., Soomro, A. aziz, Zhou, Y., Li, W., Ziniu, yu, \& Zhang, J. (2017). Cellulose decomposition and larval biomass production from the codigestion of dairy manure and chicken manure by mini-livestock ( Hermetia illucens L.). Journal of Environmental Management, 196, 458-465. https://doi.org/10.1016/j.jenvman.201 7.03.047

Salomone, R., Saija, G., Mondello, G., Giannetto, A., Fasulo, S., \& Savastano, D. (2017). Environmental impact of food waste bioconversion by insects: Application of Life Cycle Assessment to process using Hermetia illucens. Journal of Cleaner Production, 140(March 2019), 890905.

https://doi.org/10.1016/j.jclepro.2016. 06.154

Scriber, J. M., \& Slansky, F. (1981). The Nutritional Ecology of Immature Insects. Annual Review of
Entomology, 26(1), 183-211. https://doi.org/10.1146/annurev.en.26. 010181.001151

Setti, L., Francia, E., Pulvirenti, A., Gigliano, S., Zaccardelli, M., Pane, C., Caradonia, F., Bortolini, S., Maistrello, L., \& Ronga, D. (2019). Use of black soldier fly (Hermetia illucens (L.), Diptera: Stratiomyidae) larvae processing residue in peatbased growing media. Waste Management (New York, N.Y.), 95, 278-288.

https://doi.org/10.1016/j.wasman.2019 .06 .017

Sripontan, Y., Chiu, C.-I., Tanansathaporn, S., Leasen, K., \& Manlong, K. (2020). Modeling the Growth of Black Soldier Fly Hermetia illucens (Diptera: Stratiomyidae): An Approach to Evaluate Diet Quality. Journal of Economic Entomology, 113(2), 742751. https://doi.org/10.1093/jee/toz337

Supriyatna, A., \& Ukit, U. (2016). Screening and Isolation of Cellulolytic Bacteria from Gut of Black Soldier Flays Larvae (Hermetia illucens) Feeding with Rice Straw. Biosaintifika: Journal of Biology \& Biology Education, $\quad 8(3), \quad 314$. https://doi.org/10.15294/biosaintifika. v8i3.6762

Taggar, M. S. (2015). Insect cellulolytic enzymes: Novel sources for degradation of lignocellulosic biomass. Journal of Applied and Natural Science, 7, 625-630. https://doi.org/10.31018/jans.v7i2.656

Telang, A., Frame, L., \& Brown, M. R. (2007). Larval feeding duration affects ecdysteroid levels and nutritional reserves regulating pupal commitment in the yellow fever mosquito Aedes aegypti (Diptera: Culicidae). Journal 
of Experimental Biology, 210(5), 854864. https://doi.org/10.1242/jeb.02715

Tschirner, M., \& Simon, A. (2015). Influence of different growing substrates and processing on the nutrient composition of black soldier fly larvae destined for animal feed. Journal of Insects as Food and Feed, 1(4), 249-259. https://doi.org/10.3920/JIFF2014.0008

ur Rehman, K., Cai, M., Xiao, X., Zheng, L., Wang, H., Soomro, A. A., Zhou, Y., Li, W., Yu, Z., \& Zhang, J. (2017). Cellulose decomposition and larval biomass production from the codigestion of dairy manure and chicken manure by mini-livestock (Hermetia illucens L.). Journal of Environmental Management, 196, 458-465.

Wang, Y.-S., \& Shelomi, M. (2017). Review of Black Soldier Fly (Hermetia illucens) as Animal Feed and Human Food. Foods, 6(10), 91. https://doi.org/10.3390/foods6100091

Zheng, L., Hou, Y., Li, W., Yang, S., Li, Q., \& Ziniu, yu. (2012). Biodiesel production from rice straw and restaurant waste employing black soldier fly assisted by microbes. Energy, 47, 225-229. https://doi.org/10.1016/j.energy.2012. 09.006

Zheng, L., Li, Q., Zhang, J., \& Yu, Z. (2012). Double the biodiesel yield: Rearing black soldier fly larvae, Hermetia illucens, on solid residual fraction of restaurant waste after grease extraction for biodiesel production. Renewable Energy, 41, 75-79. https://doi.org/10.1016/j.renene.2011. 10.004

Zhou, F., Tomberlin, J. K., Zheng, L., Yu, Z., \& Zhang, J. (2013). Developmental and waste reduction plasticity of three black soldier fly strains (Diptera:
Stratiomyidae) raised on different livestock manures. Journal of Medical Entomology, 50(6), 1224-1230. https://doi.org/10.1603/ME13021 